\title{
Exploratory electromyography in the study of vibration-induced white finger in rock drillers
}

\author{
D S CHATTERJEE, ${ }^{*}$ D D BARWICK, ${ }^{2}$ AND ANN PETRIE ${ }^{3}$ \\ From the British Steel Corporation, ${ }^{1}$ the Neurophysiology Department, ${ }^{2}$ Newcastle General Hospital, \\ and the Department of Occupational Health and Hygiene, ${ }^{3}$ University of Newcastle upon Tyne, Newcastle \\ upon Tyne, UK
}

ABSTRACT Electrophysiological observations made in the hands of a group of 16 rock-drillers were compared with 15 controls. Motor and sensory conduction velocities in the median and ulnar nerves together with the latency, duration, and the amplitude of the evoked action potentials were measured. The differences between the groups were statistically significant mainly in latency, duration, and amplitude, especially of the sensory action potentials. Measurement of the conduction velocities, in general, proved to be less sensitive, and the only significant change observed was in the sensory conduction velocity in the median nerve when the first digit in the right hand was stimulated. The most interesting result was evidence of an increased prevalence of possible carpal tunnel syndrome in the exposed (44\% compared with $7 \%$ in the control group). A similar set of data, but exclusively sensory and not standardised for age and sex, was obtained from 25 university students for comparison with the assigned groups. The results showed that apart from sensory duration the control group had values that were closest to the students while the vibration group had values furthest away.

The question of whether vibration syndrome should be prescribed as an industrial disease in the United Kingdom has been considered by the Industrial Injuries Advisory Council since 1954. So far the Majority Report by the Industrial Diseases SubCommittee $^{1}$ has recommended against prescription. The grounds for rejection are many, but the most important is the lack of any clinical test that can establish the diagnosis of vibration-induced white finger (VWF) in an individual case. Some authors ${ }^{2-7}$ have succeeded in differentiating vibration from nonvibration workers but no tests have proved to be absolutely objective. It still remains uncertain whether VWF can be accepted as a disabling condition under the terms of the Industrial Injuries Act 1965. Most cases so far have been assessed as trivial and the associated condition of aches and pains as a temporary discomfort rather than a disease. There is evidence 89 that the individual's response to handinduced vibration depends on several extrinsic

*Present address: Ford Motor Company Ltd, Dagenham, Essex RM9 6SA.

Received 16 January 1981

Accepted 10 April 1981 (character of vibration) and intrinsic (character of body) variables and that the pathogenesis of VWF can also differ. A single test, therefore, might never be absolutely diagnostic for a multifactorial condition such as VWF. In the light of this background the present survey aimed to explore the value of electromyography in the study of the disabilities associated with, rather than the diagnosis of, VWF. This is essentially a quantitative follow-up of a previous study 10 in which the one cause for rejection of prescription could be explored objectively.

\section{Materials and methods}

Admission to the study was entirely voluntary. The assignment of the subjects to either the exposed or the non-exposed group was determined according to the previous study. Initially 33 men responded, but two were not suitable for epidemiological grouping and hence were rejected from the final analysis. The study group consisted of 16 rock-drillers exposed to a vibration level in excess of the damage level criterion ${ }^{11}$ between the frequencies of 31.5 and 62 Hertz (HZ). Their exposure varied from 18 months to 25 years (mean 10 years) and their ages from 
Table 1 Particulars of subjects and students studied

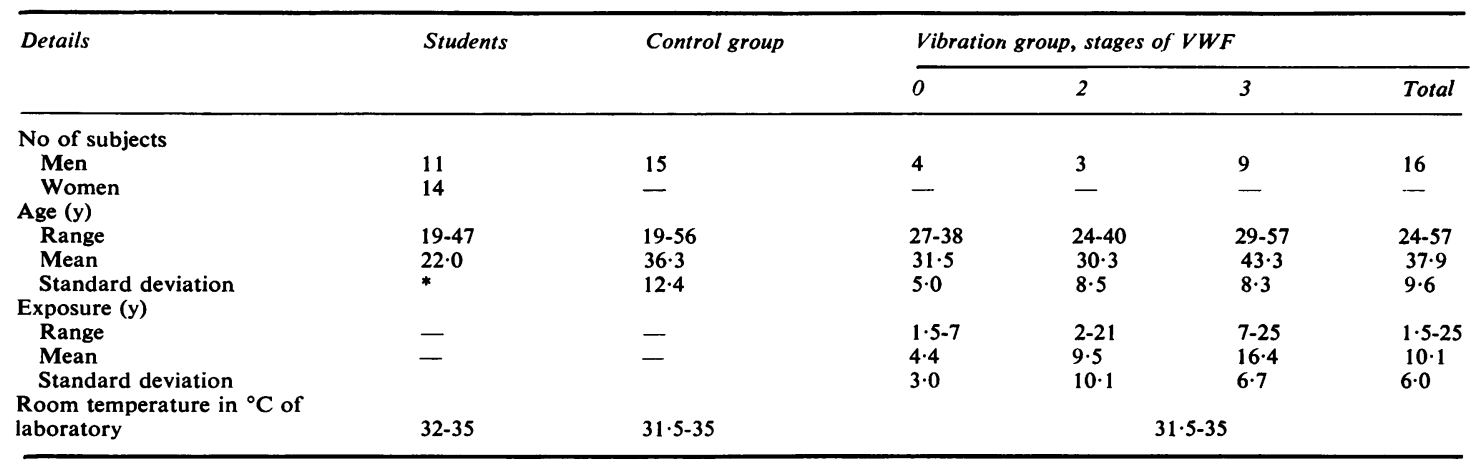

*Standard deviation for student group is not known.

24 to 57 (mean 37.9 years $(\mathrm{SD}=9.6)$ ). Four men were in clinical stage $0\left(\mathrm{~V}_{0}\right)$, three in stage $2\left(\mathrm{~V}_{2}\right)$, and nine in stage $3\left(V_{3}\right)$ of VWF. The two men in stage 0 were actually in the intermediate stage of $V_{\text {ON }}$ and $V_{\text {ONT }}$, indicating that they had symptoms of tingling or numbness, or both, but no evidence of white finger. The ages of the control group of 15 men ranged from 19 to 56 (mean $36 \cdot 3$ years $(\mathrm{SD}=12 \cdot 4)$ ); none of the controls had a history of exposure to vibration or to any neurotoxic material (table 1).

Electrophysiological studies were carried out as described by Bradley ${ }^{12}$ using a Disa-type 14 A 30 three-channel electromyograph with a 14 G 01 digital averager capable of averaging up to 1024 successive stimuli. Skin temperature was recorded with a Light Laboratories Temperature Recorder at the beginning and end of the individual measurements. When the skin temperature was found to be low, active warming up procedures were carried out, and the study did not progress until a satisfactory temperature was established. At the time of the examinations the ambient temperature of the laboratory varied from $26^{\circ} \mathrm{C}$ to $27^{\circ} \mathrm{C}$ and the skin temperature of the subjects from $31.5^{\circ} \mathrm{C}$ to $35^{\circ} \mathrm{C}$.

The motor conduction velocities of the median and ulnar nerves were determined. In the median nerve percutaneous supramaximal stimulation was carried out in the antecubital fossa and at the wrist. The distal latency to onset, amplitude, and duration of the motor action potentials were recorded with surface electrodes over the thenar muscles. Similar studies were carried out on the ulnar nerve, but in this case stimulation was applied at, as well as above and below, the elbow. Responses were recorded with surface electrodes over the hypothenar muscles. The results of the conduction velocity measurements in the ulnar nerve were calculated for the axilla to the above elbow segment of the ulnar nerve, the elbow segment, and that below the elbow, as well as the distal latency at the wrist.
For the sensory conduction velocity the digital nerves were stimulated with ring electrodes around the individual fingers, and the action potentials were recorded over the median and ulnar nerves at the wrist using surface electrodes. For each individual digit a minimum number of 32 stimuli required averaging to give a satisfactory definition. When sensory action potentials were abnormal it was necessary to increase the number of average responses to stimulation to obtain an adequately defined potential. The measurements made on the ascending orthodromic volley recorded from each digit were latency to onset, latency to peak, total potential duration, and peak-to-peak amplitude. The distance between the stimulation and the recording sites was measured and a sensory conduction velocity for each digit calculated. Six sets of results were obtained for each arm studied. A single set of values is presented for all except the fourth digit for which two similar are given, the first of the recording over the median and the second over the ulnar nerve at the wrist; this finger is supplied by both nerves. Latency and duration were measured in milliseconds (msec), amplitude in microvoltage $(\mu \mathrm{v})$, and velocity in metre/second $(\mathrm{m} / \mathrm{sec})$.

The study was carried out from June to October 1978 and only at weekends so that the subjects could travel to the hospital laboratory without any loss of time at work. About an hour was needed for testing each individual. A single investigator took the measurements, carried out the tests, and reported the results in order to reduce observer error. The investigator was unaware of the occupational history of the men and therefore the measurements were carried out blindly.

An additional set of sensory data obtained from the EMG-study of 25 university students of a somewhat different age group (19-47 years (mean 22)) and mixed sex (11 men, 14 women) was also available for comparison. Although this group was not standard- 
Table 2 Motor changes in control and vibration groups presented in four different parameters for each nerve studied

\begin{tabular}{|c|c|c|c|c|c|}
\hline \multirow[t]{2}{*}{ Parameters studied } & \multicolumn{2}{|c|}{$\begin{array}{l}\text { Control group } \\
(n=15)\end{array}$} & \multicolumn{2}{|c|}{$\begin{array}{l}\text { Vibration group } \\
(n=16)\end{array}$} & \multirow{2}{*}{$\begin{array}{l}\text { Significant differences } \\
\text { between control and } \\
\text { vibration groups }\end{array}$} \\
\hline & Mean & $(S D)$ & Mean & $(S D)$ & \\
\hline \multicolumn{6}{|l|}{ Right hand } \\
\hline Latency (msec) & $3 \cdot 8$ & $(0 \cdot 3)$ & $4 \cdot 1$ & $(0 \cdot 8)$ & $*$ \\
\hline Duration (msec) & $12 \cdot 4$ & $(2 \cdot 1)$ & $13 \cdot 7$ & $(3 \cdot 7)$ & NS \\
\hline Amplitude $(\mu \mathrm{V})$ & 11733 & $(4062)$ & 9463 & $(4036)$ & NS \\
\hline Velocity $(\mathrm{m} / \mathrm{sec})$ & $58 \cdot 7$ & $(2 \cdot 7)$ & $59 \cdot 4$ & $(5 \cdot 2)$ & NS \\
\hline \multicolumn{6}{|l|}{ Ulnar nerve } \\
\hline Latency (msec) & 3.0 & $(0 \cdot 5)$ & $3 \cdot 1$ & $(0 \cdot 4)$ & NS \\
\hline Duration (msec) & $11 \cdot 9$ & $(3 \cdot 0)$ & $12 \cdot 6$ & $(2 \cdot 8)$ & NS \\
\hline Amplitude $(\mu \mathrm{V})$ & 7900 & (2904) & 9103 & $(1118)$ & NS \\
\hline \multicolumn{6}{|l|}{ Velocity } \\
\hline Below elbow (m/sec) & $58 \cdot 4$ & $(2 \cdot 8)$ & $59 \cdot 2$ & $(3 \cdot 8)$ & NS \\
\hline Around elbow (m/sec) & $58 \cdot 2$ & $(3 \cdot 2)$ & $60 \cdot 4$ & $(3 \cdot 5)$ & NS \\
\hline Above elbow $(\mathrm{m} / \mathrm{sec})$ & $60 \cdot 8$ & $(3 \cdot 3)$ & $62 \cdot 8$ & $(3 \cdot 7)$ & NS \\
\hline \multicolumn{6}{|l|}{ Left hand } \\
\hline \multicolumn{6}{|l|}{ Median nerve } \\
\hline Latency (msec) & $3 \cdot 5 \ddagger$ & $(0 \cdot 2)$ & $4 \cdot 0$ & $(0.4)$ & + \\
\hline Duration (msec) & $12 \cdot 7 \ddagger$ & $(1 \cdot 7)$ & $12 \cdot 4$ & $(1 \cdot 5)$ & NS \\
\hline Amplitude $(\mu \mathrm{V})$ & $11536+$ & (3522) & 8941 & $(4320)$ & NS \\
\hline Velocity $(\mathrm{m} / \mathrm{sec})$ & $58 \cdot 8 \ddagger$ & $(3 \cdot 6)$ & $59 \cdot 2$ & $(3 \cdot 8)$ & NS \\
\hline \multicolumn{6}{|l|}{ Ulnar nerve } \\
\hline Latency (msec) & $2 \cdot 9$ & $(0 \cdot 5)$ & $3 \cdot 1$ & $(0 \cdot 3)$ & NS \\
\hline Duration (msec) & $11 \cdot 7$ & $(2 \cdot 0)$ & $13 \cdot 1$ & $(2 \cdot 0)$ & $*$ \\
\hline Amplitude $(\mu \mathrm{V})$ & 7767 & (3923) & 6240 & $(1890)$ & NS \\
\hline \multicolumn{6}{|l|}{ Velocity } \\
\hline Below elbow (m/sec) & $58 \cdot 1$ & $(3 \cdot 1)$ & $59 \cdot 9$ & $(3 \cdot 3)$ & NS \\
\hline Around elbow $(\mathrm{m} / \mathrm{sec})$ & $58 \cdot 3$ & $(2 \cdot 5)$ & $60 \cdot 3$ & $(2 \cdot 7)$ & $*$ \\
\hline Above elbow $(\mathrm{m} / \mathrm{sec})$ & $60 \cdot 0$ & $(3 \cdot 0)$ & $64 \cdot 4$ & $(3 \cdot 5)$ & $\dagger$ \\
\hline
\end{tabular}

* $<<0.05 ; \dagger p<0.01 ;$ NS $p>0.05$.

$\ddagger$ Based on 14 observations only.

ised for age and sex, the measurements were performed by the same investigator and under the same laboratory conditions.

\section{Results}

The results were based on the analysis of the motor

Table 3 Measurements ( $\mathrm{msec}$ ) of sensory latency (as means) to onset in students, controls, and in the vibration groups for each digit in both hands

\begin{tabular}{|c|c|c|c|c|c|c|c|}
\hline \multirow[t]{2}{*}{ Digits } & \multicolumn{2}{|c|}{ Students $(n=25)$} & \multicolumn{2}{|c|}{ Control group $(n=15)$} & \multicolumn{2}{|c|}{ Vibration group $(n=16)$} & \multirow{2}{*}{$\begin{array}{l}\text { Significant differences } \\
\text { between control and } \\
\text { vibration groups }\end{array}$} \\
\hline & Mean & $(S D)$ & Mean & $(S D)$ & Mean & $(S D)$ & \\
\hline Digit I & $2 \cdot 0$ & $(0 \cdot 2)$ & $2 \cdot 2$ & $(0 \cdot 2)$ & $2 \cdot 4$ & $(0 \cdot 3)$ & $*$ \\
\hline Digit II & $2 \cdot 1$ & $(0 \cdot 2)$ & $2 \cdot 5$ & $(0 \cdot 3)$ & $2 \cdot 9$ & $(0 \cdot 4)$ & $\dagger$ \\
\hline Digit III & $2 \cdot 3$ & $(0 \cdot 1)$ & $2 \cdot 7$ & $(0 \cdot 5)$ & $2 \cdot 9$ & $(0.6)$ & NS \\
\hline \multicolumn{8}{|l|}{ Ulnar nerve } \\
\hline Digit IV & $2 \cdot 1$ & $(0 \cdot 1)$ & $2 \cdot 5$ & $(0 \cdot 3)$ & $2 \cdot 6$ & $(0.4)$ & NS \\
\hline Digit V & $2 \cdot 1$ & $(0 \cdot 2)$ & $2 \cdot 3$ & $(0 \cdot 4)$ & $2 \cdot 4$ & $(0 \cdot 4)$ & NS \\
\hline \multicolumn{8}{|c|}{$\begin{array}{l}\text { Left hand } \\
\text { Median nerve }\end{array}$} \\
\hline Digit I & $2 \cdot 1$ & $(0 \cdot 2)$ & $2 \cdot 2$ & $(0 \cdot 3)$ & $2 \cdot 4$ & $(0 \cdot 2)$ & $*$ \\
\hline Digit II & $2 \cdot 2$ & $(0 \cdot 3)$ & $2 \cdot 6$ & $(0.5)$ & $2 \cdot 8$ & $(0 \cdot 3)$ & NS \\
\hline Digit III & $2 \cdot 2$ & $(0 \cdot 2)$ & $2 \cdot 6$ & $(0 \cdot 4)$ & $2 \cdot 8$ & $(0 \cdot 3)$ & NS \\
\hline Digit IV & $2 \cdot 3$ & $(0 \cdot 1)$ & $2 \cdot 4$ & $(0.4)$ & $2 \cdot 8$ & $(0 \cdot 3)$ & $*$ \\
\hline Digit V & $2 \cdot 0$ & $(0 \cdot 1)$ & $2 \cdot 4$ & $(0.4)$ & $2 \cdot 5$ & $(0.4)$ & NS \\
\hline
\end{tabular}

* $p<0.05 ;+p<0.01 ;$ NS $p>0.05$.

(A single set of figures was presented for each digit except the fourth, which is supplied by both median and ulnar nerves.) 
Table 4 Measurements (msec) of sensory latency (as means) to peak in the control and the vibration groups for each digit in both hands

\begin{tabular}{|c|c|c|c|c|c|}
\hline \multirow[t]{2}{*}{ Digits } & \multicolumn{2}{|c|}{$\begin{array}{l}\text { Control group } \\
(n=15)\end{array}$} & \multicolumn{2}{|c|}{$\begin{array}{l}\text { Vibration group } \\
(n=16)\end{array}$} & \multirow{2}{*}{$\begin{array}{l}\text { Significant } \\
\text { differences between } \\
\text { control and vibration } \\
\text { groups }\end{array}$} \\
\hline & Mean & $(S D)$ & Mean & $(S D)$ & \\
\hline \multicolumn{6}{|c|}{$\begin{array}{l}\text { Right hand } \\
\text { Median nerve }\end{array}$} \\
\hline $\begin{array}{l}\text { Digit I } \\
\text { Digit II } \\
\text { Digit III } \\
\text { Digit IV }\end{array}$ & $\begin{array}{l}2 \cdot 9 \\
3 \cdot 3 \\
3 \cdot 4 \\
3 \cdot 3\end{array}$ & $\begin{array}{l}(0 \cdot 3) \\
(0 \cdot 3) \\
(0 \cdot 3) \\
(0 \cdot 4)\end{array}$ & $\begin{array}{l}3 \cdot 0 \\
3 \cdot 5 \\
3 \cdot 7 \\
3 \cdot 6\end{array}$ & $\begin{array}{l}(0 \cdot 3) \\
(0 \cdot 5) \\
(0 \cdot 6) \\
(0 \cdot 7)\end{array}$ & $\begin{array}{l}\text { NS } \\
\text { NS } \\
\text { NS } \\
\text { NS }\end{array}$ \\
\hline \multicolumn{6}{|l|}{ Ulnar nerve } \\
\hline $\begin{array}{l}\text { Digit IV } \\
\text { Digit V }\end{array}$ & $\begin{array}{l}3 \cdot 1 \\
3 \cdot 0\end{array}$ & $\begin{array}{l}(0 \cdot 3) \\
(0 \cdot 4)\end{array}$ & $\begin{array}{l}3 \cdot 4 \\
3 \cdot 1\end{array}$ & $\begin{array}{l}(0.4) \\
(0.5)\end{array}$ & $\begin{array}{l}\text { NS } \\
\text { NS }\end{array}$ \\
\hline \multicolumn{6}{|c|}{$\begin{array}{l}\text { Left hand } \\
\text { Median nerve }\end{array}$} \\
\hline $\begin{array}{l}\text { Digit I } \\
\text { Digit II } \\
\text { Digit III } \\
\text { Digit IV }\end{array}$ & $\begin{array}{l}2 \cdot 9 \\
3 \cdot 3 \\
3 \cdot 3 \\
3 \cdot 1\end{array}$ & $\begin{array}{l}(0.4) \\
(0.6) \\
(0.5) \\
(0.5)\end{array}$ & $\begin{array}{l}3 \cdot 0 \\
3 \cdot 5 \\
3 \cdot 4 \\
3 \cdot 4\end{array}$ & $\begin{array}{l}(0 \cdot 3) \\
(0 \cdot 5) \\
(0 \cdot 4) \\
(0 \cdot 4)\end{array}$ & $\begin{array}{l}\text { NS } \\
\text { NS } \\
\text { NS } \\
*\end{array}$ \\
\hline \multicolumn{6}{|l|}{ Ulnar nerve } \\
\hline $\begin{array}{l}\text { Digit IV } \\
\text { Digit V }\end{array}$ & $\begin{array}{l}3 \cdot 1 \\
3 \cdot 0\end{array}$ & $\begin{array}{l}(0.5) \\
(0.5)\end{array}$ & $\begin{array}{l}3 \cdot 4 \\
3 \cdot 3+\end{array}$ & $\begin{array}{l}(0 \cdot 5) \\
(0 \cdot 4)\end{array}$ & $\begin{array}{l}\text { NS } \\
\text { NS }\end{array}$ \\
\hline
\end{tabular}

* $p<0.05 ;$ NS $p>0.05$.

$\dagger$ Based on 15 observations only.

See footnote to table 3 .

and sensory conduction velocities in both hands. As the standard deviation tends to increase with the mean the results were considered not to be normally distributed. A non-parametric test, the Mann Whitney $\mathrm{U}$ test, was therefore used to study the differences between the control and the study groups, both being in a similar age group. As the students were not standardised for age and sex no statistical test of significance was performed for comparison with the assigned groups.

\section{MOTOR CHANGES}

The motor responses shown in table 2 are expressed in means with standard deviation in parentheses. Differences between the groups were statistically significant for the mean latencies in the median nerve ( $p<0.05$ in the right and $p<0.01$ in the left hand) and for the mean duration in the left ulnar nerve $(p<0.05)$. The MCV in the left ulnar nerve was significantly different $(p<0.05$ for elbow to wrist and $p<0.01$ for above elbow to wrist)

Table 5 Measurements (msec) of sensory duration (as means) in students, controls, and in the vibration group for each digit in both hands

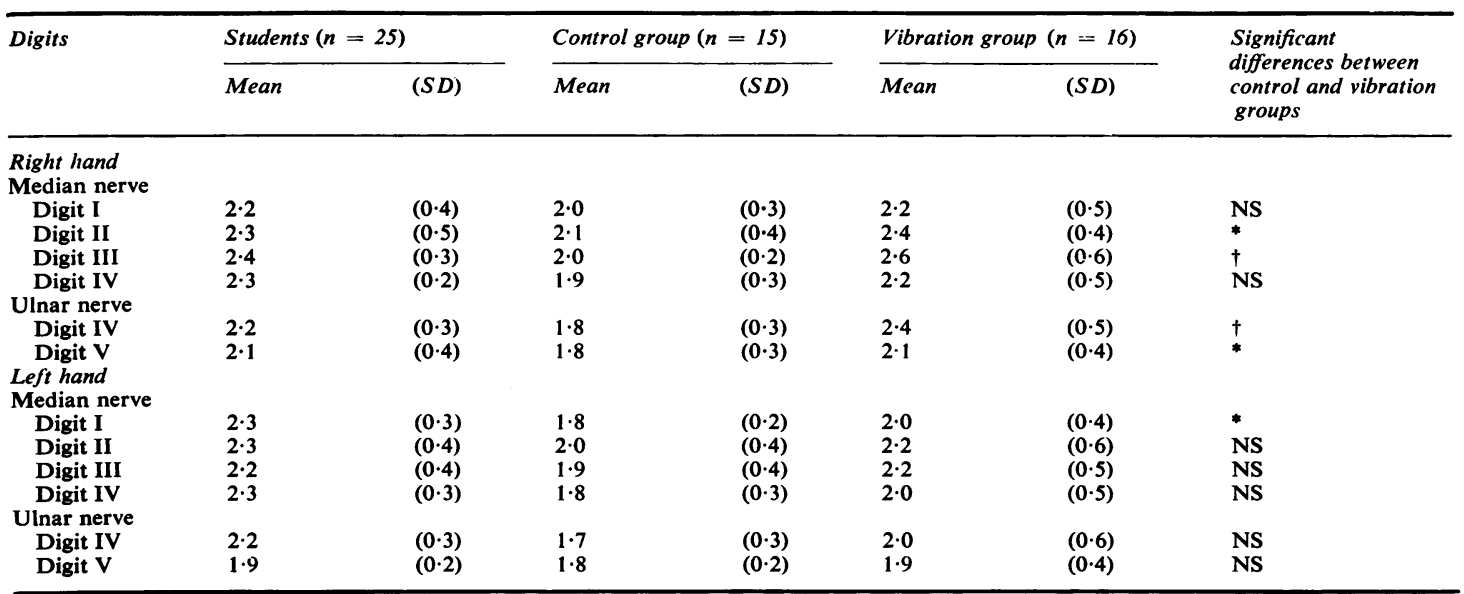

p $<<0.05 ; \dagger p<0.001 ;$ NS $p>0.05$

See footnote to table 3 . 
between the groups but the rate was faster in the exposed than in the non-exposed group.

\section{SENSORY CHANGES}

The detailed sensory responses are shown in tables $3-8$; the significant differences between the groups may be highlighted as follows.

\section{Sensory latency (table 3)}

The mean latency to onset varied from $2.4 \mathrm{msec}$ to $2.9 \mathrm{msec}$ in the exposed group and from $2.2 \mathrm{msec}$ to $2.7 \mathrm{msec}$ in the non-exposed group. Differences between the groups were significant in the first ( $p<0.05)$, second ( $p<0.01)$, and fourth $(p<0.05)$ digits supplied by the median nerve in the right hand and the first and fourth digits $(p<0.05)$ supplied by the median nerve in the left hand. By comparison, the mean latencies in the students varied from $2.0 \mathrm{msec}$ to $2.3 \mathrm{msec}$ and are shorter than those in both the control and vibration groups (table 4). Corresponding values for the latency to peak were from $3.0 \mathrm{msec}$ to $3.7 \mathrm{msec}$ in the vibration group and from $2.9 \mathrm{msec}$ to $3.4 \mathrm{msec}$ in the controls. The only statistically significant difference between the groups was in the fourth digit supplied by the median nerve in the left hand (table 4).

Sensory duration (table 5)

The mean duration of sensory action potentials in each digit differed significantly between the right and the left hand. Values varied from $2 \cdot 1 \mathrm{msec}$ to $2 \cdot 6 \mathrm{msec}$ in the right hand and from $1.9 \mathrm{msec}$ to $2.2 \mathrm{msec}$ in the left. No such variation was observed between the hands in the controls, their means ranging be- tween $1.8 \mathrm{msec}$ and $2.1 \mathrm{msec}$. The results were statistically significant in the second $(p<0.05)$ and third $(\mathrm{p}<0.001)$ digits supplied by the right median; the fourth $(p<0.001)$ and fifth $(p<0.05)$ digits supplied by the right ulnar, and the first digit $(p<0.05)$ supplied by the left median nerves. The students with mean values varying from $1.9 \mathrm{msec}$ to $2.4 \mathrm{msec}$ occupied an intermediate position between the two main groups.

\section{Sensory amplitude (table 6)}

The mean amplitudes in the vibration group differed in the right and in the left hands with values that varied from $2.8 \mu \mathrm{V}$ to $8.8 \mu \mathrm{V}$ in the right hand and from $3.6 \mu \mathrm{V}$ to $11 \mu \mathrm{V}$ in the left. In the controls and in the students the right hand had higher values than the left. The mean amplitudes in the individual digits, however, were much higher in the controls $(4 \cdot 3-26 \mu \mathrm{V})$ and highest $(9 \cdot 0-22 \cdot 0 \mu \mathrm{V})$ in the students. The difference between the control and the vibration groups was significant in the first $(\mathrm{p}<0.05)$, second $(p<0.05)$, third $(p<0.01)$, and fourth $(p<0.01)$ digits supplied by the median nerve and the other half of the fourth digit $(p<0.05)$ supplied by the ulnar nerve in the right hand.

Further analysis of the amplitudes showed that seven men in the exposed group and one of the controls had electromyographic evidence of possible carpal tunnel syndrome (table 7) with sensory amplitudes of the index fingers being at least $1 \mu \mathrm{V}$ lower than that of the little fingers. The reverse is usually found.Of the seven men in the vibration group, two belonged to the clinical stage of $V_{0}$, one to stage $V_{2}$, and four to stage $V_{3}$ of VWF. Bilateral

Table 6 Measurements ( $\mu V$ ) of sensory amplitude (as means) in students, controls, and in the vibration group for each digit in both hands

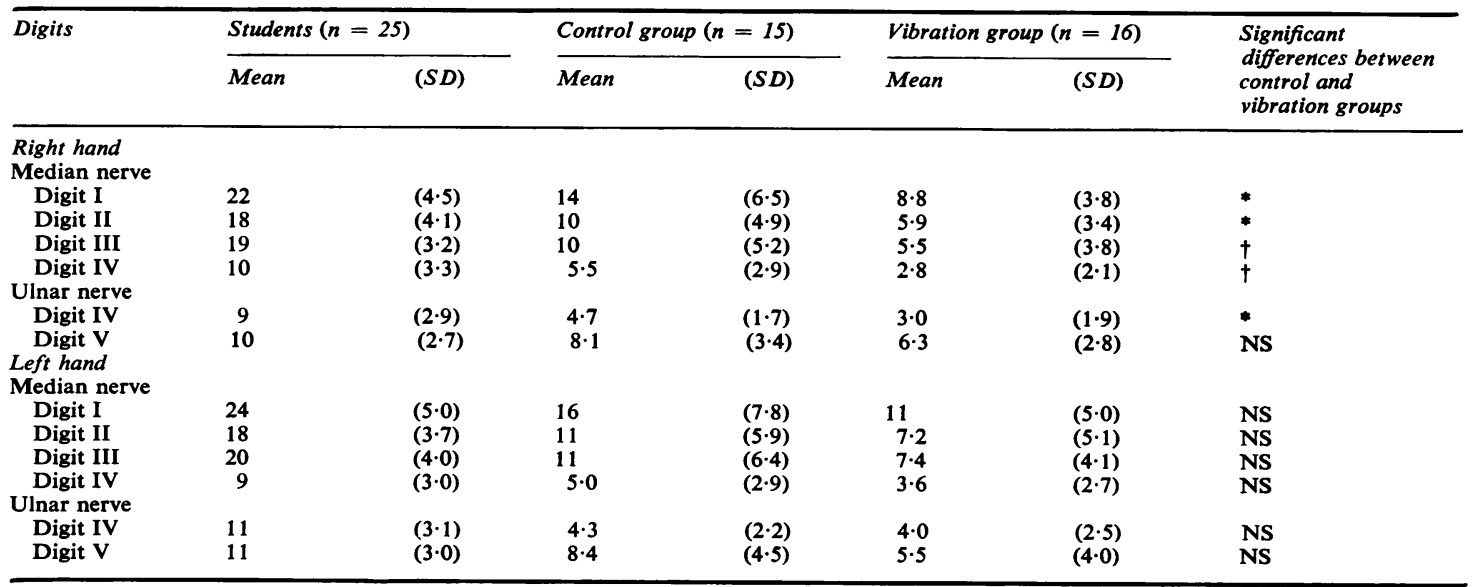

* $p<0.05 ; \dagger p<0.01 ; N S p>0.05$.

See footnote to table 3 . 
Table 7 Prevalence of carpal tunnel syndrome in control and vibration groups

\begin{tabular}{lllll}
\hline Groups & No in each group & $\begin{array}{l}\text { No with } \\
\text { carpal tunnel } \\
\text { syndrome }\end{array}$ & $\begin{array}{l}\text { No without } \\
\text { carpal tunnel } \\
\text { syndrome }\end{array}$ & $\begin{array}{l}\text { Significant differences } \\
\text { between control and } \\
\text { vibration groups }\end{array}$ \\
\hline Control & 15 & 1 & 14 & $\begin{array}{l}\text { Fisher's exact test }= \\
0.037\end{array}$ \\
Vibration & 16 & 7 & 9 & $\begin{array}{l}\chi^{2} \text { test }=\mathrm{p}<0 \cdot 05 \\
\text { (Yates's correction) }\end{array}$ \\
Total & 31 & 8 & 23 & \\
\hline
\end{tabular}

(NB Diagnosis of carpal tunnel syndrome is based solely on relationship of amplitudes of digital action potentials evoked from fingers supplied by median and ulnar nerves.)

changes were found in four men; in the rest only the right hand was affected. The $\chi^{2}$ test showed that the difference between the groups for this syndrome was statistically significant $(\mathrm{p}<0.05)$.

Sensory conduction velocity (table 8 )

The mean SCVs in the digits varied from $47.0 \mathrm{~m} / \mathrm{sec}$ to $52.0 \mathrm{~m} / \mathrm{sec}$ in the vibration group and from $51.0 \mathrm{~m} / \mathrm{sec}$ to $53.0 \mathrm{~m} / \mathrm{sec}$ in the control group. The difference between the groups was significant $(p<0.05)$ only in the first digit supplied by the median nerve in the right hand. The results were much higher $(55 \cdot 0-60.0 \mathrm{~m} / \mathrm{sec})$ in the students.

\section{Discussion}

The results summarised in table 9 strongly suggest that neurophysiological changes often occur in subjects who regularly use vibratory tools. From the table it may be seen that, with the exception of the sensory duration, the median nerve is affected more than the ulnar nerve. Statistically the difference between the groups is significant for motor and sensory latencies $(p<0.05)$, sensory duration $(p<0.01)$, and sensory amplitude $(p<0.05)$ in the median nerve and only for sensory duration $(p<0.001)$ in the ulnar nerve. Whether these changes are related to VWF or not is difficult to say, since they do not show any specific relationship with the different stages of VWF. This may be partly due to the fact that the total number of men studied was small and because some of the men in the stage $V_{0}$ of VWF did, in fact, belong to the intermediate stage of $V_{0 N}$ and $V_{\text {ONT. }}$. With the exception of sensory duration, the students had values that were closer to but higher than the controls. The variation observed in the sensory duration is difficult to explain, but the other changes could be regarded as a function of age and exposure to hard work. Normally there is a systemic negative correlation between age and conduction velocity. ${ }^{13-15}$ The students, being in the lower age group, will therefore be expected to have higher values. Apart from this age factor, it is not uncommon to find neuropathy by sensitive methods ${ }^{16}$ among working populations whose work entails

Table 8 Measurements $(\mathrm{m} / \mathrm{sec}$ ) of sensory velocity (as means) in students, controls, and in the vibration group for each digit in both hands

\begin{tabular}{|c|c|c|c|c|c|c|c|}
\hline \multirow[t]{2}{*}{ Digits } & \multicolumn{2}{|c|}{ Students $(n=25)$} & \multicolumn{2}{|c|}{ Control group $(n=15)$} & \multicolumn{2}{|c|}{ Vibration group $(n=16)$} & \multirow{2}{*}{$\begin{array}{l}\text { Significant differences } \\
\text { between control and } \\
\text { vibration groups }\end{array}$} \\
\hline & Mean & $(S D)$ & Mean & $(S D)$ & Mean & $(S D)$ & \\
\hline \multicolumn{8}{|c|}{$\begin{array}{l}\text { Right hand } \\
\text { Median nerve }\end{array}$} \\
\hline $\begin{array}{l}\text { Digit I } \\
\text { Digit II } \\
\text { Digit III } \\
\text { Digit IV }\end{array}$ & $\begin{array}{l}55 \\
58 \\
60 \\
56\end{array}$ & $\begin{array}{l}(5 \cdot 3) \\
(5 \cdot 7) \\
(4 \cdot 9) \\
(5 \cdot 1)\end{array}$ & $\begin{array}{l}51 \\
51 \\
51 \\
51\end{array}$ & $\begin{array}{l}(4 \cdot 0) \\
(5 \cdot 9) \\
(5 \cdot 4) \\
(5 \cdot 6)\end{array}$ & $\begin{array}{l}48 \\
48 \\
48 \\
47\end{array}$ & $\begin{array}{l}(6 \cdot 6) \\
(8 \cdot 0) \\
(9 \cdot 7) \\
(8 \cdot 1)\end{array}$ & $\begin{array}{l}* \\
\text { NS } \\
\text { NS } \\
\text { NS }\end{array}$ \\
\hline Ulnar nerve & & & & & & & \\
\hline $\begin{array}{l}\text { Digit IV } \\
\text { Digit V } \\
\text { Left hand } \\
\text { Median nerv }\end{array}$ & $\begin{array}{l}57 \\
56\end{array}$ & $\begin{array}{l}(4 \cdot 4) \\
(4 \cdot 4)\end{array}$ & $\begin{array}{l}51 \\
52\end{array}$ & $\begin{array}{l}(4 \cdot 5) \\
(5 \cdot 0)\end{array}$ & $\begin{array}{l}51 \\
52\end{array}$ & $\begin{array}{l}(8 \cdot 6) \\
(8 \cdot 6)\end{array}$ & $\begin{array}{l}\text { NS } \\
\text { NS }\end{array}$ \\
\hline $\begin{array}{l}\text { Digit I } \\
\text { Digit II } \\
\text { Digit III } \\
\text { Digit IV }\end{array}$ & $\begin{array}{l}57 \\
56 \\
59 \\
60\end{array}$ & $\begin{array}{l}(3 \cdot 7) \\
(4 \cdot 5) \\
(3 \cdot 9) \\
(5 \cdot 0)\end{array}$ & $\begin{array}{l}51 \\
51 \\
51 \\
51\end{array}$ & $\begin{array}{l}(4 \cdot 5) \\
(5 \cdot 9) \\
(6 \cdot 5) \\
(5 \cdot 9)\end{array}$ & $\begin{array}{l}48 \\
49 \\
50 \\
49\end{array}$ & $\begin{array}{l}(6 \cdot 1) \\
(7 \cdot 1) \\
(7 \cdot 9) \\
(7 \cdot 3)\end{array}$ & $\begin{array}{l}\text { NS } \\
\text { NS } \\
\text { NS } \\
\text { NS }\end{array}$ \\
\hline $\begin{array}{l}\text { Ulnar nerve } \\
\text { Digit IV } \\
\text { Digit V }\end{array}$ & $\begin{array}{l}55 \\
54\end{array}$ & $\begin{array}{l}(3 \cdot 7) \\
(4 \cdot 1)\end{array}$ & $\begin{array}{l}53 \\
52\end{array}$ & $\begin{array}{l}(5 \cdot 5) \\
(4 \cdot 9)\end{array}$ & $\begin{array}{l}51 \\
52\end{array}$ & $\begin{array}{l}(8 \cdot 6) \\
(8 \cdot 2)\end{array}$ & $\begin{array}{l}\text { NS } \\
\text { NS }\end{array}$ \\
\hline
\end{tabular}

* $\mathrm{p}<0.05 ; \mathrm{NS} \mathrm{p}>0.05$.

See footnote to table 3 . 
Table 9 Main electrophysiological changes in means by the median and ulnar nerves and the clinical stages of VWF

\begin{tabular}{|c|c|c|c|c|c|c|c|}
\hline \multirow[t]{2}{*}{ Parameters studied } & \multirow{2}{*}{$\begin{array}{l}\text { Control group } \\
(n=15)\end{array}$} & \multicolumn{3}{|l|}{ Vibration group } & \multicolumn{3}{|c|}{ Significant differences between } \\
\hline & & $\begin{array}{l}V_{0}+V_{2}+V_{3} \\
(n=16)\end{array}$ & $\begin{array}{l}V_{z}+V_{3} \\
(n=12)\end{array}$ & $\begin{array}{l}V_{3} \\
(n=9)\end{array}$ & $\begin{array}{l}\text { Control and } \\
V_{0}+V_{2}+V_{3}\end{array}$ & $\begin{array}{l}\text { Control and } \\
V_{z}+V_{3}\end{array}$ & $\begin{array}{c}\text { Control and } \\
V_{3}\end{array}$ \\
\hline \multicolumn{8}{|c|}{ Motor latency (msec) } \\
\hline Median nerve & $3 \cdot 7$ & $4 \cdot 0$ & $4 \cdot 0$ & $4 \cdot 0$ & $*$ & $*$ & $*$ \\
\hline Ulnar nerve & $2 \cdot 9$ & $3 \cdot 0$ & $3 \cdot 0$ & $3 \cdot 0$ & NS & NS & NS \\
\hline \multicolumn{8}{|l|}{$\begin{array}{l}\text { Sensory latency } \\
\text { (msec) }\end{array}$} \\
\hline Median nerve & $2 \cdot 5$ & $2 \cdot 7$ & $2 \cdot 8$ & $2 \cdot 7$ & $*$ & $*$ & NS \\
\hline Ulnar nerve & $2 \cdot 4$ & $2 \cdot 5$ & $2 \cdot 6$ & $2 \cdot 5$ & NS & NS & NS \\
\hline \multicolumn{8}{|l|}{$\begin{array}{l}\text { Sensory amplitude } \\
\text { (msec) }\end{array}$} \\
\hline Median nerve & $10 \cdot 4$ & $6 \cdot 5$ & $6 \cdot 2$ & 6.9 & $*$ & $*$ & NS \\
\hline Ulnar nerve & 6.4 & 4.9 & $4 \cdot 7$ & $5 \cdot 1$ & NS & NS & NS \\
\hline \multicolumn{8}{|l|}{$\begin{array}{l}\text { Sensory duration } \\
\text { (msec) }\end{array}$} \\
\hline Median nerve & 1.9 & $2 \cdot 2$ & $2 \cdot 2$ & $2 \cdot 3$ & $\dagger$ & $\dagger$ & $t$ \\
\hline Ulnar nerve & $1 \cdot 8$ & $2 \cdot \overline{1}$ & $2 \cdot 1$ & $2 \cdot 2$ & $\ddagger$ & $\ddagger$ & $\ddagger$ \\
\hline
\end{tabular}

$* \mathrm{p}<0.05 ; \dagger p<0.01 ; \ddagger \mathrm{p}<0.001 ; \mathrm{NS} p>0.05$.

excessive use of their hands. This explains the reason for some overlapping between the vibration and the control groups in certain results, the latter being drawn from the manual workers.

A very basic problem experienced in the present study was the difficulty in comparing the results in terms of the so-called normal EMG values. A study in Helsinki ${ }^{17}$ on 120 healthy adults aged from 20 to 60 showed that the lowest limit of the MCVs in the nerves of the arm was $50 \mathrm{~m} / \mathrm{sec}$, that of SCV, 48 $\mathrm{m} / \mathrm{sec}$, and the upper limit of motor latency of the median nerve was $4.8 \mathrm{msec}$. In a similar study in Scotland ${ }^{18}$ the comparative values of MCVs in the median and ulnar nerves were $45 \mathrm{~m} / \mathrm{sec}$ and $46 \mathrm{~m} / \mathrm{sec}$ respectively, those of SCVs, $36 \mathrm{~m} / \mathrm{sec}$ and $38 \mathrm{~m} / \mathrm{sec}$, and of the motor latency of the median nerve, $4.1 \mathrm{msec}$. The MCVs in the present study were closer to the results of the Finnish study and the SCVs to those of the Scottish study. This indicates that the normal values in EMG are widespread and they vary considerably from one laboratory to the other. It was therefore difficult to establish a cut-off point in any parameter for comparison between the abnormal and the so-called normal values.

Previous studies ${ }^{19-22}$ have shown that a standard method of measuring conduction velocity is usually not sensitive. The factors shown in these studies to be the most sensitive in differentiating between the exposed and the non-exposed workers were the distal latency of the median and the conduction velocity of the slower motor fibres (CVSF) ${ }^{23}$ of the ulnar nerves. The latter is based on the partial antidromic block by simultaneously stimulating the nerve at two different points. The present study, such as others in the past, shows that the conduction velocity alone is not a reliable criterion for the diagnosis of mild neuropathy but, unlike them, it highlights that other parameters, especially the sensory parameters, are valuable discriminants. Similar abnormalities in sensory action potentials have been shown to provide a delicate sign of peripheral nerve lesion. ${ }^{24}$

In addition, the increased evidence of possible carpal tunnel syndrome in the exposed group, shown in the present study, furthers the scope of routine electromyography. In general, the sensory action potentials recorded from the ulnar nerve when the little finger is stimulated is smaller and less easy to measure than those recorded from the median nerve when the index finger is stimulated. ${ }^{25}$ In $44 \%$ of our exposed group, but in only $7 \%$ of the controls, the sensory amplitudes showed an inverse relationship between the index and the little finger providing indirect evidence of carpal tunnel syndrome. ${ }^{26}$

It can perhaps be argued that these changes might be due to digital neuropathy and not to carpal tunnel syndrome. While it is impossible to exclude this possibility, we believe that the results are more suggestive of carpal tunnel syndrome for several reasons. Firstly, on further analysis the mean motor latency in the median nerve at the wrist had a higher value in the individuals with possible carpal tunnel syndrome $(4.3 \pm 0.5 \mathrm{msec})$ than those without this syndrome $(3.9 \pm 0.6 \mathrm{msec})$, whereas the mean motor latencies in the ulnar nerve remained unchanged $(3.1 \pm 0.4 \mathrm{msec})$ in both subgroups. Secondly, we examined the amplitudes of the action potentials from the digits other than the index finger. The sensory amplitudes of the fourth finger which is supplied by both the median and ulnar nerves were analysed separately in the individuals where carpal tunnel syndrome had been postulated 
and in those where it had not. The individuals thought to have carpal tunnel syndrome showed a low mean sensory amplitude $(2.9 \pm 1.9 \mu \mathrm{V})$ in the median and a much larger amplitude $(4.0 \pm 1.3 \mu \mathrm{V})$ in the ulnar nerve. In the group without the syndrome the results were similar in both nerves $(3.2 \pm 2.5 \mu \mathrm{V}$ in the median and $3.1 \pm 2.5 \mu \mathrm{V}$ in the ulnar). It is difficult to believe that neuropathy would regularly affect only the median side of the ring finger or even the median nerve alone.

In a previous study 27 a similar syndrome has been described among $21 \%-32.8 \%$ of the vibrationexposed workers in stimulation electromyography. The same study also illustrated that mononeuropathy may have an aetiology other than vibratory tools, but the simultaneous abnormalities in several nerves are compatible with vibration neuropathy. This is very much evident in the present study, showing the statistically significant differences between the groups predominantly in sensory parameters other than SCV. According to Dawson ${ }^{25}$ this could be because the sensory fibres from the fingers are larger than the motor fibres to the hand. In conclusion, the study shows that the hand-arm syndrome associated with VWF is not simply a "discomfort" but a manifestation of vibration neuropathy and possibly of carpal tunnel syndrome at the wrist.

The occupational origin of this disability is not difficult to diagnose when it is associated with a history of significant exposure to vibration and white finger. Therefore, the hypothesis that the diminished tactile sensitivity observed on aesthesiometry testing may not be due to any change in function at the neuronal or receptor levels, but rather to some thickening or change in plasticity of the skin, can be discarded.

We wish to express our sincere thanks to Professor R I McCallum, Department of Occupational Health and Hygiene, University of Newcastle upon Tyne, for his support in the planning stage of the study and for his valuable comments on reading the manuscript; to Dr D M Fanning, chief medical officer, British Steel Corporation, for helping in the publications search and approving this paper for publication; to Mr F Harrison, manager, ore mines, British Steel Corporation, for his support and help in obtaining the volunteers, and, most of all, to the men in the fluorspar mines without whose help this study would not have materialised.

\section{References}

${ }^{1}$ Industrial Injuries Advisory Council. Vibration syndrome. Cmn 5965. London: HMSO, 1970.

2 Agate JN. An outbreak of cases of Raynaud's phenomenon of occupational origina. Br J Ind Med 1949;6:144-63.

3 Jepson RP. Raynaud's phenomenon-a review of the clinical problem. Ann $R$ Coll Surg Engl 1951;9:35-51.

4 Jepson RP. Raynaud's phenomenon in workers with vibratory tools. $\mathrm{Br} J$ Ind Med $1954 ; 11: 180-5$.

${ }^{5}$ Stewart AM, Goda DF. Vibration syndrome. Br J Ind Med 1970;27:19-27.

${ }^{6}$ Hellstrom B, Myhre K. A comparison of some methods of diagnosing Raynaud's phenomena of occupational origin. Br J Ind Med 1971;28:272-9.

7 Taylor W, Pelmear PL. Vibration white finger in industry. London: Academic Press, 1975.

${ }^{8}$ Reynolds DD, Soedel W. Dynamic response of the handarm system to a sinusoidal input. British Journal of Sound and Vibration 1972;21:339-53.

9 Reynolds DD. Hand-arm vibration-A review of three years research. In: Wasserman DE, Taylor W, eds. Proceedings of the international occupational hand-arm vibration conference, Cincinnati. Ohio : US Dept of Health, Education and Welfare,1977:99-128. (Publication No 77-170.)

${ }^{10}$ Chatterjee DS, Petrie A, Taylor W.Prevalence of vibrationinduced white finger in fluorspar mines in Weardale. Br J Ind Med 1978;35:208-18.

${ }^{11}$ British Standards Institution. Guide for the evaluation of human exposure to hand-arm system vibration. London: BSI, 1975. (Draft for development DD43.)

12 Bradley WG. Disorders of peripheral nerves. Oxford: Blackwell Scientific Publications, 1974:86-8.

${ }^{13} \mathrm{La}$ Fratta CW, Smith $\mathrm{OH}$. A study of the relationship of motor nerve conduction velocity in the adult to age, sex and handedness. Arch Phys Med Rehabil 1964;45:407-12.

${ }^{14}$ Seppäläinen AM, Toivakka EI. Effect of age and sex on median nerve conduction in normal adults. Scand J Clin Lab Invest 1970;25:113, 87.

${ }^{15}$ Nielson VK. Sensory and motor nerve conduction in the median nerve in normal subjects. Acta Med Scand 1973; $194: 435-43$.

16 Seppäläinen AM, Tolonen M. Neurotoxicity of long-term exposure to carbon disulphide in the viscose rayon industry: neurophysiological study. Work-Environment Health 1974;11:145-53.

17 Seppäläinen AM. Neurophysiological detection of vibration syndrome in the shipbuilding industry. In: Korhonen $\mathrm{O}$, ed. Proceedings of the Finnish-Soviet-Scandinavian vibration symposium in Helsinki 1975: vibration and work. Helsinki: Instutute of Occupational Health, 1976:63-71.

${ }^{18}$ Lenman JAR, Ritchie AE. Clinical electromyography. 2nd ed. London: Pitman Medical and Scientific, 1977: 60-130.

19 Seppäläinen AM. Nerve conduction in the vibration syndrome. Work-Environment Health 1970;7:82-4.

${ }^{20}$ Seppäläinen AM, Hernberg S. Sensitive technique for detecting subclinical lead neuropathy. Br J Ind Med 1972; 29:443-9.

${ }^{21}$ Alaranta H, Seppäläinen AM. Neuropathy and automatic analysis of electromyographic signals from vibration exposed workers. Scand J Work Environ Health 1977;3: 128-34.

22 Bhuiatti E, Cecchini S, Ronchi O, Dolora P, Bulgarelli G. Relationship between clinical and electromyographic findings and exposure to solvents in shoe and leather workers. Br J Ind Med 1978;35:168-73.

${ }^{23}$ Hopf HCh. Untersuchungen Uber die unterschiede in der LeitgeschwindigKeit motorischer Nervenfasern beim Mensehen. Deutsche Zeitschrift für Nervenheilkunde 1962;193:579-88.

24 Gilliatt RW, Sears TA. Sensory nerve action potentials in patients with peripheral nerve lesions.J Neurol Neurosurg Psychiatry 1958;21:109-18. 
${ }^{25}$ Dawson GD. The relative excitability and conduction velocity of sensory and motor nerve fibres in man. $J$ Physiol 1956;131:436-51.

${ }^{26}$ Loong SC, Seah CS. Comparison of median and ulnar nerve action potentials in the diagnosis of the carpal tunnel syndrome. J Neurol Neurosurg Psychiatry 1971;
$34: 750-4$.

27 Louda L, Lukes E. Hygiene aspects of occupational hand-arm vibration. In: Wasserman DE, Taylor W, eds. International occupational hand-arm vibration conference 1975. Ohio: US Dept of Health, Education and Welfare, 1977:60-8. (Publication No 77-170.)

\section{Vancouver style}

All manuscripts submitted to the $B r J$ Ind Med should conform to the uniform requirements for manuscripts submitted to biomedical journals (known as the Vancouver style).

The $\mathrm{Br} J$ Ind $\mathrm{Med}$, together with many other international biomedical journals, has agreed to accept articles prepared in accordance with the Vancouver style. The style (described in full in $\mathrm{Br}$ Med J, 24 February 1979, p 532) is intended to standardise requirements for authors.

References should be numbered consecutively in the order in which they are first mentioned in the text by Arabic numerals above the line on each occasion the reference is cited (Manson ${ }^{1}$ confirmed other reports ${ }^{2-5} \ldots$ ). In future references to papers submitted to the $B r J$ Ind Med should include: the names of all authors if there are six or less or, if there are more, the first three followed by et al; the title of journal articles or book chapters; the titles of journals abbreviated according to the style of Index Medicus; and the first and final page numbers of the article or chapter.

Examples of common forms of references are:

${ }^{1}$ International Steering Committee of Medical Editors. Uniform requirements for manuscripts submitted to biomedical journals. Br Med J 1979;1 :532-5.

2 Soter NA, Wasserman SI, Austen KF. Cold urticaria: release into the circulation of histamine and eosinophil chemotactic factor of anaphylaxis during cold challenge. N Engl J Med 1976;294:687-90.

${ }^{3}$ Weinstein L, Swartz MN. Pathogenic properties of invading micro-organisms. In: Sodeman WA Jr, Sodeman WA, eds. Pathologic physiology: mechanisms of disease. Philadelphia: W B Saunders, 1974:457-72. 